\title{
Social Work Practice in a Developing Continent: The Case of Africa
}

\author{
Christopher Chitereka
}

\begin{abstract}
Social work is a professional approach to ameliorating social problems. It is generally understood as a helping profession that utilizes professionally qualified personnel who use its knowledge base to help people tackle their social problems (Mupedziswa, 2005). Nevertheless, in developing countries, social work is a relatively young profession which was influenced by colonialism in its formation. The type of social work practiced in these countries largely mirrors the one that is being practiced in Britain, France and Portugal among others. Utilizing the continent of Africa as a case study, this article argues that social work practice in Africa tends to be curative or remedial in nature and is not adequately addressing people's problems. It therefore proposes a paradigm shift from remedial to a social development paradigm if it is to make an impact in the $21^{\text {st }}$ century.
\end{abstract}

Keywords: Social work; social development; Africa

\section{INTRODUCTION}

Social work is a profession which seeks to help and empower vulnerable groups in society such as women, persons with disabilities, children and the elderly as well as people living with HIV/AIDS. In 2000, the two professional representative bodies, the International Federation of Social Workers and the International Association of Schools of Social Work adopted the following definition of social work:

The social work profession promotes social change, problem solving in human relationships and the empowerment and liberation of people to enhance wellbeing. Utilizing theories of human behavior and social systems, social work intervenes at the points where people interact with their environments. Principles of human rights and social justice are fundamental to social work (International Federation of Social Workers, 2000, para. 1).

That definition of social work will also be adopted for purposes of this article. The article seeks to discuss social work practice in Africa. The basic argument advanced by the article is that the curative or remedial approach which is currently used in many African countries is not adequately addressing the needs of the majority of the population which resides largely in rural areas of the continent. It therefore advocates for the adoption of the social development paradigm. It first highlights the genesis of the profession of social work in Africa. It then goes on to mention some of the problems faced by the African continent. The article then discusses social work in Africa and the social development paradigm. It finally provides the conclusion and way forward.

Christopher Chitereka, MSW, is a Senior Lecturer in Social Work in the Department of Social Anthropology/Sociology and Social Work at The National University of Lesotho.

Copyright (c) 2009 Advances in Social Work Vol. 10 No. 2 (Fall 2009), 144-156 


\section{GENESIS OF THE SOCIAL WORK PROFESSION IN AFRICA}

Over the past few years, social work has expanded to virtually every corner of the world (Darkwa, 2007). Factors such as the fall of communism in the Soviet Union (Hokenstad \& Kendall, 1995), the emergence of democratic institutions in Africa, and the impact of the technological revolution have all contributed to the globalization of social work. In Africa, a number of factors played an influential role in facilitating the emergence of social work. The activities of missionaries from Europe and other parts of the world, African mutual aid societies, and the colonization of the continent by external powers all contributed to social work development on the continent. The missionaries preceded the colonizers. Even though their primary role focused on addressing the religious and spiritual needs of Africans, by establishing schools, vocational training, and engaging in almsgiving and community work, the missionaries functioned as informal social workers (Darkwa, 2007). Tribal and mutual aid societies have always existed in Africa. Prior to the development of statutory welfare systems, different types of mutual aid societies across the continent provided assistance to family members. Some were family or kin-based (the largest category); others were cultural- and/or religious-based (such as rotating credit societies, and informal service societies) (Midgley, 1997). The African extended family, for example, has always operated as a social welfare system (Apte \& Grieco, 1994), and they continue to address the social welfare needs of a sizeable number of Africans who lack any form of social protection.

However, on a more professional note, social work in Africa is a relatively young profession introduced in the 1960s. Although the first school of social work-the Cairo School of Social Work in Egypt-was established way back in 1937 (Yiman, 1990), the profession did not take root until the 1960s. Most African countries were once colonized and they attained independence in rapid succession in the 1960s. Asamoah (1995) notes that although there are many regional differences with regards to social problems, economic growth, social development and political arrangements, newly independent countries south of the Sahara had inadequate political and social infrastructures to support rapid social change and industrial development. Social work in Africa was generally influenced by and molded after activities in the colonizing powers, including Britain, France and Portugal, among others (Mupedziswa, 2005). Today, one can safely conclude that social work now exists as a profession in most African countries with some countries like Zimbabwe, South Africa, Zambia, Ethiopia, Swaziland, Nigeria, Uganda, Ghana, Kenya, Tanzania, Rwanda and Egypt training their own social workers. The training normally takes place in Universities. Basically, however, the approach of social work practice which was introduced and which remains in force in many African countries is the curative or remedial approach. This approach is really reactive and dealing with the symptoms and not the real causes of problems. A section below will highlight this issue in greater detail.

\section{PROBLEMS FACED BY THE AFRICAN CONTINENT}

The continent of Africa, home to more than 50 nations, is often dismissed as a continent of vast natural resources and primitive societies, governed by military dictators 
who change regularly. In fact, getting past the sensationalist headlines, one finds democratic governments struggling to get a foothold on this continent as well. Many nations in Africa have severe social problems which are threatening the moral fiber of societies. Research has shown that one of the main triggers of social problems in Africa is the scourge of poverty (Muzaale, 1987). Despite the fact that Africa is potentially the richest continent on the planet, it is actually the poorest. For instance, studying poverty figures in Africa produces a daunting picture. 315 million people: one in two people in Sub Saharan Africa survive on less than one dollar per day. 184 million people: 33\% of the African population suffers from malnutrition (United Nations Development Programme, 2007). With regard to poverty of income, it is estimated that "just under three million households in South Africa live on less than R1000 a month, approximately 105 Euro" (Monama, 2006, p. 3). Poverty, manifesting itself in the form of the majority spending less than a dollar a day on their livelihood, degraded environment, and homelessness, is increasing at an alarming rate in Africa and is mainly caused by corrupt regimes which do not care for the welfare of their citizens. It has been reported that the late Presidents Sani Abacha of Nigeria and Mobutu Sese Seko of the former Zaire looted their countries' resources and had off-shore accounts. Some current African leaders are still plundering their countries' resources leading to the majority of their citizens wallowing in poverty.

Food insecurity is also a critical underlying factor that interfaces directly with extreme poverty particularly among the vulnerable groups. Many African countries experience continued starvation year in and year out despite the rich and unexploited potential for increased food production. Unreliable weather conditions, poor food security policies, high costs of fertilizers and other farm inputs, prohibitive transportation costs, lack of credit facilities for farmers and competition for markets created by global forces are contributory factors to food insecurity in Africa.

Another serious problem facing most African countries is that of rampant unemployment. In South Africa for instance, current unemployment rates range around $40 \%$ of the economically active population. The correlation between unemployment and poverty is significant in that $55 \%$ of people from poor households are unemployed, compared with $14 \%$ of those from non-poor households (May, 1998). Many people are out of employment including university graduates. The rate of unemployment is likely to increase in the next few years considering the current global economic crisis. It can be argued that the problem of unemployment has led to other social ills such as prostitution, human trafficking, teenage pregnancies and high crime rates in Africa.

African countries also face unending civil wars and conflict among and within countries. Conflicts in Darfur-Sudan, Uganda and Chad are some of the long-running ones on the continent and they have caused untold suffering among the ordinary people. This has led to a high number of people becoming refugees. Refugees greatly strain the host countries' resources and violent confrontations often occur between the refugees and the local population, like what happened in May, 2008 in South Africa when South African citizens attacked people from other African countries. These conflicts and civil wars also lead to the abuse of women and children. Child soldiers are now a rampant phenomenon in most conflict zones in Africa. For instance, Ariyo (2005) notes that out of 
300,000 child soldiers around the world, it is estimated that 120,000 of these are African children who have been forced and recruited to take part in wars and fighting in some African countries. The Lord's Resistance Army, a rebel group in Uganda, is known to have a lot of child soldiers among its ranks. Girl children are also being used as sex slaves by the rebels. So, in a nutshell, wars and conflicts in Africa violate basic human rights, destabilize families and communities, and impact negatively on food production.

Africa has been affected most severely by the HIV/AIDS pandemic on the planet. The sub-Saharan Africa region has the highest infection rates in the world. The pandemic escalated in the region mainly due to the denial of the existence of the disease by most African leaders. By the time they acknowledged its existence, many people had been infected. An estimated 22 million adults and children were living with HIV in subSaharan Africa at the end of 2007. During that year, an estimated 1.5 million Africans died from AIDS. The epidemic has left behind some 11.6 million orphaned African children (Avert, 2009). The estimated number of adults and children living with HIV/AIDS, the number of deaths from AIDS, and the number of living orphans in individual countries in sub-Saharan Africa at the end of 2007 are shown below.

\begin{tabular}{|c|c|c|c|c|c|c|}
\hline Country & $\begin{array}{r}\text { People } \\
\text { living with } \\
\text { HIV/AIDS }\end{array}$ & $\begin{array}{r}\text { Adult } \\
(15-49) \\
\text { rate \% }\end{array}$ & $\begin{array}{c}\text { Women with } \\
\text { HIV/AIDS }\end{array}$ & $\begin{array}{r}\text { Children } \\
\text { with HIV/ } \\
\text { AIDS }\end{array}$ & $\begin{array}{r}\text { AIDS } \\
\text { deaths }\end{array}$ & $\begin{array}{r}\text { Orphans } \\
\text { due to } \\
\text { AIDS }\end{array}$ \\
\hline Angola & 190,000 & 2.1 & 110,000 & 17,000 & 11,000 & 50,000 \\
\hline Benin & 64,000 & 1.2 & 37,000 & 5,400 & 3,300 & 29,000 \\
\hline Botswana & 300,000 & 23.9 & 170,000 & 15,000 & 11,000 & 95,000 \\
\hline Burkina Faso & 130,000 & 1.6 & 61,000 & 10,000 & 9,200 & 100,000 \\
\hline Burundi & 110,000 & 2.0 & 53,000 & 15,000 & 11,000 & 120,000 \\
\hline Cameroon & 540,000 & 5.1 & 300,000 & 45,000 & 39,000 & 300,000 \\
\hline Central African Republic & 160,000 & 6.3 & 91,000 & 14,000 & 11,000 & 72,000 \\
\hline Chad & 200,000 & 3.5 & 110,000 & 19,000 & 14,000 & 85,000 \\
\hline Comoros & $<200$ & $<0.1$ & $<100$ & $<100$ & $<100$ & $<100$ \\
\hline Congo & 120,000 & 3.5 & 43,000 & 6,600 & 6,400 & 69,000 \\
\hline Côte d'Ivoire & 480,000 & 3.9 & 250,000 & 52,000 & 38,000 & 420,000 \\
\hline Dem. Republic of Congo & $\begin{array}{r}400,000- \\
500,000\end{array}$ & $\begin{array}{r}1.2- \\
1.5\end{array}$ & $\begin{array}{r}210,000- \\
270,000\end{array}$ & $\begin{array}{r}37,000- \\
52,000\end{array}$ & $\begin{array}{r}24,000- \\
34,000\end{array}$ & $\begin{array}{r}270,000- \\
380,000\end{array}$ \\
\hline Djibouti & 16,000 & 3.1 & 8,700 & 1,100 & 1,100 & 5,200 \\
\hline Equatorial Guinea & 11,000 & 3.4 & 5,900 & $<1,000$ & $<1,000$ & 4,800 \\
\hline Eritrea & 38,000 & 1.3 & 21,000 & 3,100 & 2,600 & 18,000 \\
\hline Ethiopia & 980,000 & 2.1 & 530,000 & 92,000 & 67,000 & 650,000 \\
\hline Gabon & 49,000 & 5.9 & 27,000 & 2,300 & 2,300 & 18,000 \\
\hline Gambia & 8,200 & 0.9 & 4,500 & $<1,000$ & $<1,000$ & 2,700 \\
\hline Ghana & 260,000 & 1.9 & 150,000 & 17,000 & 21,000 & 160,000 \\
\hline
\end{tabular}




\begin{tabular}{|c|c|c|c|c|c|c|}
\hline Country & $\begin{array}{r}\text { People } \\
\text { living with } \\
\text { HIV/AIDS } \\
\end{array}$ & $\begin{array}{r}\text { Adult } \\
(15-49) \\
\text { rate \% }\end{array}$ & $\begin{array}{r}\text { Women with } \\
\text { HIV/AIDS }\end{array}$ & $\begin{array}{r}\text { Children } \\
\text { with HIV/ } \\
\text { AIDS } \\
\end{array}$ & $\begin{array}{r}\text { AIDS } \\
\text { deaths }\end{array}$ & $\begin{array}{r}\text { Orphans } \\
\text { due to } \\
\text { AIDS } \\
\end{array}$ \\
\hline Guinea & 87,000 & 1.6 & 48,000 & 6,300 & 4,500 & 25,000 \\
\hline Guinea-Bissau & 16,000 & 1.8 & 8,700 & 1,500 & 1,100 & 6,200 \\
\hline Kenya & $\begin{array}{r}1,500,000- \\
2,000,000\end{array}$ & $\begin{array}{r}7.1- \\
8.5\end{array}$ & $\begin{array}{r}800,000- \\
1,100,000\end{array}$ & $\begin{array}{r}130,000- \\
180,000\end{array}$ & $\begin{array}{c}85,000- \\
130,000\end{array}$ & $\begin{array}{r}990,000- \\
1,400,000\end{array}$ \\
\hline Lesotho & 270,000 & 23.2 & 150,000 & 12,000 & 18,000 & 110,000 \\
\hline Liberia & 35,000 & 1.7 & 19,000 & 3,100 & 2,300 & 15,000 \\
\hline Madagascar & 14,000 & 0.1 & 3,400 & $<500$ & $<1,000$ & 3,400 \\
\hline Malawi & 930,000 & 11.9 & 490,000 & 91,000 & 68,000 & 560,000 \\
\hline Mali & 100,000 & 1.5 & 56,000 & 9,400 & 5,800 & 44,000 \\
\hline Mauritania & 14,000 & 0.8 & 3,900 & $<500$ & $<1,000$ & 3,000 \\
\hline Mauritius & 13,000 & 1.7 & 3,800 & $<100$ & $<1,000$ & $<500$ \\
\hline Mozambique & $1,500,000$ & 12.5 & 810,000 & 100,000 & 81,000 & 400,000 \\
\hline Namibia & 200,000 & 15.3 & 110,000 & 14,000 & 5,100 & 66,000 \\
\hline Niger & 60,000 & 0.8 & 17,000 & 3,200 & 4,000 & 25,000 \\
\hline Nigeria & $2,600,000$ & 3.1 & $1,400,000$ & 220,000 & 170,000 & $1,200,000$ \\
\hline Rwanda & 150,000 & 2.8 & 78,000 & 19,000 & 7,800 & 220,000 \\
\hline Senegal & 67,000 & 1.0 & 38,000 & 3,100 & 1,800 & 8,400 \\
\hline Sierra Leone & 55,000 & 1.7 & 30,000 & 4,000 & 3,300 & 16,000 \\
\hline Somalia & 24,000 & 0.5 & 6,700 & $<1,000$ & 1,600 & 8,800 \\
\hline South Africa & $5,700,000$ & 18.1 & $3,200,000$ & 280,000 & 350,000 & $1,400,000$ \\
\hline Swaziland & 190,000 & 26.1 & 100,000 & 15,000 & 10,000 & 56,000 \\
\hline Togo & 130,000 & 3.3 & 69,000 & 10,000 & 9,100 & 68,000 \\
\hline Uganda & $1,000,000$ & 6.7 & 520,000 & 110,000 & 91,000 & $1,000,000$ \\
\hline United Rep. Of Tanzania & 940,000 & 5.4 & 480,000 & 130,000 & 77,000 & $1,200,000$ \\
\hline Zambia & $1,100,000$ & 15.2 & 560,000 & 95,000 & 56,000 & 600,000 \\
\hline Zimbabwe & $1,300,000$ & 15.3 & 680,000 & 120,000 & 140,000 & $1,000,000$ \\
\hline Total sub-Saharan Africa & $22,000,000$ & 5.0 & $12,000,000$ & $1,800,000$ & $1,500,000$ & $11,600,000$ \\
\hline
\end{tabular}

SOURCE: UNAIDS/WHO (2008.).

The above statistics paint a grim picture for Africa's long-term development. HIV and AIDS have had a great impact in all spheres of life. Avert (2009) observes that taking care of a person sick with AIDS is not only an emotional strain for household members, but also a strain on household resources. Loss of income, additional care-related expenses, the reduced ability of care-givers to work, and mounting medical fees push affected households deeper into poverty. The financial burden of death can also be considerable, with some families in South Africa easily spending seven times their total 
household monthly income on a funeral. The AIDS epidemic adds to food insecurity in many areas, as agricultural work is neglected or abandoned due to household illness. In Malawi, where food shortages have had a devastating effect, it has been recognized that by 2020, Malawi's agricultural workforce will be $14 \%$ smaller than it would have been without HIV and AIDS. In other countries, such as Mozambique, Botswana, Namibia and Zimbabwe, the reduction is likely to be over 20\% (Avert, 2009). Children have also been greatly affected by the pandemic. The epidemic not only causes children to lose their parents or guardians, but sometimes their childhood as well. As parents and family members become ill, children take on more responsibility to earn income, produce food and care for family members. It is harder for these children to access adequate nutrition, basic health care, housing and clothing. Many children are now raised by their grandparents or left on their own in child-headed households (Avert, 2009).

Finally, most African countries face the problem of homelessness especially in urban areas. The majority of the people lack shelter and they stay in squatter camps and slums. For instance, Kenya is home to one of the world's largest squatter settlement known as Kibera which is located in the capital city of Nairobi. Other countries like South Africa also have large informal settlements where poor people stay in shacks without access to basic social welfare services. According to Chitereka (2005) the "ABC” (abstinence, be faithful and condomise) model for managing HIV/AIDS is hampered in the slums and other informal settlements by overcrowding, a lack of essential facilities and poor communication among other factors. Slums have serious implications for the prevention, treatment and care strategies for HIV/AIDS. Improper housing to a greater extent contributes to the spread of HIV/AIDS among the vulnerable women and categories such as widows and women with disabilities, domestic workers, girls and elderly women. Young girls are often exposed to early sexual intercourse, higher frequencies of unwanted pregnancies and exposure to rape (Chitereka, 2005).

The world cannot afford to overlook the problems faced by Africa. It is a continent in great need and social workers, being helping professionals who seek to liberate and empower people, should be in the forefront of finding solutions to these problems. The nest section highlights the need for the adoption of the social development paradigm by social workers in Africa to tackle the above-named problems.

\section{SOCIAL WORK IN AFRICA AND THE SOCIAL DEVELOPMENT PARADIGM}

Social work in most African countries embraced the curative or remedial approach to solving social problems during its inception. For instance, Kaseke (1991) notes that the development of social work in Zimbabwe is closely tied to the country's colonial history, its orientation reflecting a wholesale transfer from the British experience. He goes on to say that social work in Zimbabwe also developed as a response to urban social ills such as crime, prostitution and destitution. The philosophy of the colonial policy makers was that such ills, if unattended, would undermine order and stability. Social work was, therefore, seen primarily as an instrument of social control, and never seriously addressed itself to the root of social problems. Even after independence, the Department of Social 
Welfare, the largest employer of social workers, continues to be basically curative in orientation.

Nyanguru (2003) also notes that that in Lesotho, social work practice was introduced during the colonial era by the British. It was mainly introduced to deal with social problems in the country. Social welfare services were offered in such specialized areas as psychiatry and health sectors. They were basically remedial in nature and did not really address the causes of the problems. Darkwa (2007) gives the example of Ghana which was strongly influenced by the British welfare system during the 108 years of British colonization. He observes that the evolution of social work education and practice in Ghana was based on British principles and values. The British were mainly interested in supporting the welfare of those who were of crucial importance to the goals of furthering the colonization of the country, i.e. the civil service. As a result, social work education and practice was oriented towards addressing the needs of those working in the formal sector and it was curative in orientation.

To date, the colonial influence still shapes social work training and practice in Ghana. However, of late, the country is experiencing a trend toward the localization of social work education and more specifically, the programs are evolving to become more relevant to the needs of the Ghanaian people (Darkwa, 2007). Francophone African countries such as Senegal and Ivory Coast also inherited the French social welfare system which was largely remedial in nature and did not serve the needs of the vast majority of the people in these countries. Services were mostly concentrated in urban areas where a few people stayed at the expense of rural areas where the majority of the people stayed. This situation continues to this day.

The development of social welfare systems, social work practice and social work education must be understood within the historical context of each country's pre-colonial and post-colonial experience. The basic institutions (political, legal, social, economic and educational) of all African countries both influenced and were influenced by the formal response to the meeting of human need (Asamoah, 1995). Britain exported a remedial model which was based on the principles underlying remedial services in the United Kingdom. Therefore, services in former British colonies focused on rehabilitation and, not surprisingly, selected as the unit of attention vulnerable individuals including women, migrants, homeless children, the disabled, juvenile delinquents, the unemployed, and the physically and mentally ill (Asamoah, 1995) social policies and systems in former French colonies and territories reflected the more comprehensive approach embodied in the French Overseas Labor Code. Neither the British nor the French approach placed much emphasis on prevention. Prevailing social problems were targeted for cure, and a developmental focus was virtually non-existent. Asamoah (1995) also argues that, perhaps even more important, many of the approaches and practices labeled social work were not compatible with the cultural traditions of the countries in which they were carried out but they continued for many years.

It is clear that even after attaining their independence most African countries are still using the remedial or curative approach in dealing with social problems in their countries. The majority of social workers are employed in departments of social welfare whilst 
others are employed in correctional services and hospitals, police and defense forces and industries where the remedial approach is usually used. A few are employed by NonGovernmental Organizations (NGOs).The social workers employed by NGOs normally use the community work method and they are contributing a lot to most African countries' development. For instance Fikre Mariam Worku the founder of the NGO Misericordia Ethiopia in an interview by Alain Leterrier (2000) says that if there is no development, social work is not important. If you have to solve the problems of people, you have to work for development as well as for social work. She goes on to say, "What I mean is that social work to be effective has to be sustainable. People have to be self autonomous, they have to help themselves, and that is development. So for me, social work is another side of development" (Worku quoted in an interview by Leterrier 2000, p. 1). Midgley (1981) coined the term "professional imperialism" to highlight the continued use by developing countries of western oriented social work practice. He also laments the use of remedial social work especially in African countries where problems are vast. The casework method which is normally utilized by social workers in the departments of social welfare in most African countries is clearly inadequate to meet the challenges and immense problems faced by the continent. Mupedziswa (2005) also argues that this strategy takes insufficient cognizance of the social and economic reality of the situation in Africa, for instance, the culture, poverty levels and squalid conditions. The remedial approach has been accused of lacking in terms of sensitivity to the demands of African culture. It tends to ignore traditional, informal forms of welfare and the role of the extended family network in particular, in social welfare provision. Public assistance, which thrived on the granting of means-tested handouts, for instance, has routinely not taken cognizance of the reciprocity that is synonymous with traditional African communities, rendering its interventions and programs virtually ineffective.

Mupedziswa (2005) further notes that a major concern has also been that the remedial approach in social work in Africa has tended to ignore concerns of a more developmental nature, such as unemployment, inadequate shelter, homelessness, illiteracy, disease and ignorance, while concentrating on individual pathologies. As a result of this, many critics (Gray, Coates \& Bird 2008; Ose-Hwedie \& Rankhopo, 2008) argue that social work practice in its present form is virtually ineffective. Worku in the interview by Leterrier (2000) says that she perceives that social work in Africa is different from social work in Europe. In Europe she argues, you might have to work with people with psychological problems but in Africa social work has to focus on the poverty, the problem of people. If you work on poverty, you work for development so there is a strong link. There is, therefore, need for a paradigm shift if social work in Africa is to make a difference in the lives of the majority of the population in the $21^{\text {st }}$ century. For social work to be effective in the African context, the author proposes the adoption of the social development paradigm by social workers.

It is widely accepted that a social development paradigm is both appropriate and necessary for the African context, and social development has significantly influenced social work theory, policy and practice on the continent (Cox \& Pawal, 2005; Gray \& Fook, 2004, Patel, 2005). Indeed, this approach seeks to liberate and empower people instead of having them rely on the State for assistance. There are so many problems in 
Africa which can be ameliorated by the social development approach. Healy (2008) notes that among the many development concepts, social development is particularly important to social work. Social development acknowledges the importance of social factors in ensuring that development improves human well-being, arguing that development should be a holistic process. It aims to integrate social with economic factors. As Midgley (1995) explains: social development "is a process of planned social change designed to promote the well-being of the population as a whole in conjunction with a dynamic process of economic development” (p.25).

Social development also gives emphasis to outcomes of improving well-being of the poor and processes that emphasize participation. Paiva's (1977) early definition of social development is a very vital one: "The goal and substance of social development is the welfare of the people, as determined by the people themselves, and the consequent creation or alteration of institutions so as to create a capacity for meeting human needs at all levels (especially those at the lower levels) and for improving the quality of human relationships and relationships between people and social institutions” (p. 329).

It includes the ideas of participation, institution building, and distributive justice, key concepts in social development. Omer (1979) defined social development as "a goal and a process that aims to achieve an integrated, balanced and unified (social and economic) development of society" (p. 15). Healy (2008) observes that these elements of early social work definitions of social development are repeated in more current United Nations definitions. The International Forum for Social Development, an initiative of the UN Secretariat, characterizes social development as a set of objectives, a process, and a perspective. Advances in social development mean advances in the well-being of the person and the harmonious functioning of society. It includes improvements in individual and family well-being through the enjoyment of human rights, the provision of economic opportunities, the reduction of poverty, and access to social security, social protection and social services. It includes also the building or maintenance of social relations, structures and institutions through which individuals and groups constitute a viable society (United Nations, 2002).

Healy (2008) notes that in some parts of the world, social work redefined itself as social development to align the profession more closely with national objectives. This was particularly true in parts of Asia. Midgley (1999) also recommends human capital development, social capital development, and productive employment projects as social development intervention strategies relevant for social work.

Indeed, African countries should embrace the social development paradigm because, unlike curative or remedial social work, it makes people self-reliant. Many people in these countries usually depend on their governments especially during times of crises. If a social development paradigm is adopted by social workers in African countries, more people will be more self-conscious and aware of their rights. Issues of corruption and poor governance will be minimized as the majority of the people will participate in issues affecting their welfare. A strong correlation exists between good governance and positive social development outcomes. Although good governance on its own does not necessarily lead to improved quality of life, it is perhaps the single most important determinant factor 
in eradicating poverty, reducing development disparities, and minimizing the occurrence of several other human-generated tensions, conflicts and social problems in Africa, and often calls for social workers' interventions. Corruption, unethical practices and all other associated vices are principal manifestations of poor governance.

\section{CONCLUSION AND THE WAY FORWARD}

Although social work is a relatively young profession in Africa, it has over the years developed into a viable profession. It is now integrated in most government departments of social welfare, hospitals, correctional services, police and defense forces where the casework method is mainly dominant. Social workers employed in NGOs can be commended because by and large they utilize the community work method of social work in the course of their work, which is consistent with the social development paradigm. The profession of social work in Africa nevertheless faces a number of problems which need to be addressed urgently if it is to effectively deliver social services to the majority of people who are mainly poverty stricken. Some of the problems include lack of resources- both material and financial, low wages and salaries for social work professionals coupled with poor conditions of service as well as lack of proper professional recognition of social workers in Africa. These will be briefly explained below.

Firstly, most social workers in Africa lack both material and financial resources to carry out their duties. This a result of insufficient allocations of budget funds for the social services. There has been a general decline in social welfare budgets throughout Africa in the last few years, yet there are more social problems which need to be tackled. Social workers often lack basic items like offices, telephones and computers as well as transport to carry out home visits. This completely compromises their effectiveness to deliver services.

Secondly, there remains a considerable lag in wages and salaries between social workers and those employed in other sectors in Africa. Furthermore, their working conditions are not very attractive. They work long hours and carry heavy caseloads. Because of these reasons, highly qualified social workers in Africa have left the profession altogether whilst some have left the continent to work in countries like Britain, USA, New Zealand, Canada and Australia where salaries and conditions are comparatively better.

Finally, there is a general lack of professional recognition of social workers in Africa. This is due to the fact that most people do not understand what social work is, even among some government officials. That is the reason why in countries like Lesotho and Zimbabwe people with no training sociologists and political scientists are employed as "social workers".

Social workers in Africa have to raise awareness on the HIV/AIDS pandemic which is threatening to decimate the people on the African continent. They must lobby governments to provide anti-retroviral drugs to HIV positive people. Social workers should also help in the destigmatization of the disease so that more people get tested and get treatment early. 
If social workers are to be taken seriously as a profession in Africa, they should form strong professional associations in their respective countries which in turn lobby for their rights with governments. These professional associations will also highlight the need for increased budget allocations for the social welfare sectors by governments as well as improve wages, salaries and conditions of service for social workers.

In conclusion, Africa is a continent with great developmental potential but it is still mired by a myriad of social problems which require social work intervention. Social workers in Africa need to be proactive rather than reactive when dealing with these problems. Although the curative or remedial approach which hitherto has been the major form of intervention is still needed, social workers need to adopt the social development paradigm if they are to effectively confront the various problems currently facing the continent. Social development leads to an improvement to people's quality of life. Once people see real changes in their lives because of social work intervention, they will ultimately respect the profession and value social work services.

\section{References}

Apte, N. \& Grieco, M. (1994). Urbanization, caring for the elderly people and the changing African family: The challenge to social policy. International Security Review, 47(3-4), 111-121.

Ariyo, D. (2005). The future lost: The economic and social consequences of child abuse in Africa. Retrieved March 7, 2009 from: www.AfricaEconomicAnalysis.org.

Avert. (2009). The impact of HIV \& AIDS on Africa. Retrieved April 27, 2009 from: www.avert.org./aids-impact.africa.htm.

Asamoah, Y. W. (1995). Africa. In T. D. Watts, D. Elliott \& N. S. Mayadas (Eds.), International handbook on social work education, (pp.223-239). Westport, CT: Greenwood Press.

Chitereka, C. (2005). The impact of HIV/AIDS on development and the role of social workers: The case of Lesotho. In G. Jacques \& G. N. Lesetedi (Eds.), The new partnership for Africa's development: Debates, opportunities and challenges (pp.384-398). Pretoria: Africa Institute of South Africa.

Cox, D., \& Pawal, M. (2005). International social work: Issues, strategies and programs. Newbury Park, CA: Sage Publications.

Darkwa, O. K. (2007). Continuing social work education in an electronic age: The opportunities and challenges facing social work educators in Ghana. Professional Development, 2(1), 38-43.

Gray, M., \& Fook, J. (2004). The quest for a universal social work: Some issues and implications. Social Work Education, 23(5), 625-644.

Gray, M., Coates, J., \& Bird, M.Y. (Eds.). (2005). Indigenous social work around the world. Cornwall: Ashgate. 
Healy, L. N. (2008). International social work: Professional action in an interdependent world. New York: Oxford University Press.

Hokenstad, M. C., \& Kendall, K. A. (1995). International social work education. In R. L. Edwards (Ed.), Encyclopedia of social work $\left(19^{\text {th }}\right.$ ed., pp.1511-1520).Washington, DC: NASW Press.

International Federation of Social Workers. (2000). Definition of social work. Retrieved November 30, 2009 from: http://www.ifsw.org/p38000279.html.

Kaseke, E. (1991). Social work practice in Zimbabwe. Journal of Social Development in Africa, 6(1), 33-45.

Leterrier, A. (2000). Fikre Mariam Worku the founder of the NGO Misericordia Ethiopia, combines basic social work and help for development. Retrieved June 6, 2009 from: http://www.lesnouvelles.org/P10_magazine/15_grandentretien/15015_fikremariam2e ng.html.

May, J. (Ed.). (1998). Poverty and inequality in South Africa: Report prepared for the Office of the Executive Deputy President and the Inter-Ministerial Committee for Poverty and Inequality. Summary report. Durban: Praxis Publishing.

Midgley, J. (1981). Professional imperialism. London: Heinemann Educational Books.

Midgley, J. (1995). Social development: The development perspective in social welfare. London: Sage Publications.

Midgley, J. (1997). Social welfare in a global context. Thousand Oaks, CA: Sage Publications.

Midgley, J. (1999). Social development in social work: Learning from global dialogue. In C. Ramanathan \& R. Links (Eds.), All our futures: Principles \& resources for social work practice in a global era (pp. 193- 205). Belmont, CA: Brooks/Cole.

Monama, M. (2006, October 1). Poverty punishes SA workers. City Press.

Mupedziswa, R. (2005). Challenges and prospects of social work services in Africa. In J. C. Akeibunor \& E. E. Anugwom (Eds.), The social sciences and socio-economic transformation in Africa (pp. 271-317). Nsukka: Great AP Express Publishing.

Muzaale, P. (1987). Social development, rural poverty, and implications for fieldwork practice. Journal of Social Development in Africa, 2(1), 75-85.

Nyanguru, A. C. (2003). The strengths and weaknesses of the Department of Social Welfare in Lesotho. Maseru: Lesotho Law Reform Commission.

Omer, S. (1979). Social development. International Social Work, 22(3), 11-26.

Osei-Hwedie, K., \& Rankopo, M. (2008). Developing culturally relevant social work education in Africa: The Case of Botswana. In M. Gray, J. Coates \& M.Y. Bird (Eds.), Indigenous social work around the world (pp. 203-219). Cornwall: Ashgate. 
Paiva, J. F. X. (1977). A conception of social development. Social Service Review, 51, 327-336.

Patel, L. (2005). Social welfare and social development in South Africa. Cape Town: Oxford University Southern Africa.

UNAIDS/WHO. (2008). Report on the global AIDS epidemic. Geneva: United Nations.

United Nations. (2002, February 7-8). Financing global social development: Report. Paper presented at International Forum for Social Development, New York.

United Nations Development Program. (2007). Facts on poverty in Africa. Retrieved April 27, 2009 from: www.africa2015.org/factspoverty.

Yiman, A. (1990). Social development in Africa 1950-1985. Avebury: Aldershot.

\section{Author's note:}

Address correspondence to: Christopher Chitereka, The National University of Lesotho, Department of Social Anthropology/Sociology and Social Work, P.O. Roma 180, Roma, Lesotho. Email: chitereka@yahoo.co.uk. 